\title{
Sustainable tourism in the digital age: Institutional and economic implications
}

\author{
Gordon Rausser \\ University of California, Berkeley, Berkeley, United States \\ e-mail: rausser@berkeley.edu \\ Wadim Strielkowski \\ University of California, Berkeley, Berkeley, United States \\ e-mail: strielkowski@berkeley.edu \\ Elena Korneeva \\ Financial University, Moscow; \\ Togliatti State University, Togliatti, Russia, e-mail: ENKorneeva@fa.ru
}

Citation: Rausser G., Strielkowski W., Korneeva E. (2021). Sustainable tourism in the digital age: Institutional and economic implications. Terra Economicus 19(4): 141-159. D0I: 10.18522/20736606-2021-19-4-141-159

The term "sustainable tourism" has been in the core of the tourism industry since the last decades of the 20 th century due to the globalization and digitalization of the world economy that have also led to many institutional changes. Sustainable development is now a part of tourism strategies and visions, especially when it comes to the possible links between tourism and its impact on sustainable development. In addition, the ubiquitous digitalization has also made a significant impact on both. In this paper, we analyze the role of the sustainable tourism in the digital age using the example of the Burning Man festival, an annual event held in Nevada desert each year around Labour Day weekend with nearly sixty thousand people gathering to build a temporary city full of art, music, and interactivity. Our study is based on a unique own survey questionnaire administered at Burning Man festival in 2017. We use the travel cost method for computing the non-market valuation of demand from visiting Burning Man and show how digitalization helped the event to survive amidst the COVID-19 pandemic. In addition, this paper outlines the impact that the relationship between tourism, digitalization, and sustainable development can have on the economic growth and the institutional change. We argue that sustainable tourism can meet the needs of the current tourism industry (both domestic and international), while protecting the environment, promoting future opportunities, as well as taking into account the long-term impact of tourism on local communities and the local and international economy.

Keywords: sustainable tourism; digitalization; institutional change; travel cost method; consumer surplus

JEL codes: Q21, Q26, Z10, Z30 


\title{
Устойчивытй туризм в эпоху цифровьгх технологий: институциональные и экономические последствия
}

\author{
Гордон Рауссер \\ Калифорнийский университет, Беркли, Беркли, США \\ e-mail: rausser@berkeley.edu \\ Вадим Стриелковски \\ Калифорнийский университет, Беркли, Беркли, США \\ e-mail: strielkowski@berkeley.edu \\ Елена Корнеева \\ Финансовый университет при Правительстве РФ, Москва; \\ Тольяттинский государственный университет, Тольятти, Россия \\ e-mail: ENKorneeva@fa.ru
}

Цитирование: Rausser G., Strielkowski W., Korneeva E. (2021). Sustainable tourism in the digital age: Institutional and economic implications. Terra Economicus 19(4): 141-159. D0I: 10.18522/2073-6606-2021-19-4-141-159

Термин «устойчивый туризм» лежит в основе индустрии туризма с последних десятилетий ХХ в. из-за глобализации и цифровизации мировой экономики, которые также привели ко многим институциональным изменениям. Устойчивое развитие теперь является частью туристических стратегий, особенно когда речь идет о возможных связях между туризмом и его влиянием на устойчивое развитие. Кроме того, повсеместная цифровизация также оказала значительное влияние на то и на другое. Мы анализируем роль устойчивого туризма в эпоху цифровых технологий на примере фестиваля Burning Man, ежегодного мероприятия, проводимого в пустыне Невада каждый год в выходные дни Дня труда, когда около шестидесяти тысяч человек собираются, чтобы построить временный город искусства, музыки и интерактивности. Наше исследование основано на уникальном собственном опросе, проведенном на фестивале Burning Man в 2017 2. Мы используем метод путевых расходов для расчета нерыночной оценки спроса на посещение Burning Man и показываем, как цифровизация помогла мероприятию выжить в условиях пандемии COVID-19. Кроме того, в этом документе описывается влияние, которое взаимосвязь между туризмом, цифровизацией и устойчивым развитием может оказать на экономический рост и институциональные изменения. Мы утверждаем, что устойчивый туризм может удовлетворить потребности нынешней индустрии туризма (как внутреннего, так и международного), защищая при этом окружающую среду, продвигая будущие возможности, а также принимая во внимание долгосрочное влияние туризма на местные сообщества, локальную и международную экономику.

Ключевые слова: устойчивый туризм; цифровизация; институциональные изменения; метод расчета стоимости проезда; потребительский излишек

\section{Introduction}

Everyone would probably agree that before the lockdowns caused by the COVID-19 pandemic that unexpectedly delivered a devastating blow to the usual order of things in 2020, tourism has contributed significantly to the world economy and generated high revenues and jobs (Jeyacheya, Hampton, 
2020; Qiu et al., 2020; Strielkowski et al., 2021a). Tourism strategies of many countries that are often developed in a cooperation with many agents and stakeholders, propose an ambitious agenda for the future development of the tourism sector as a whole with a regional focus in particular (Moravčíková, Dvoŕák, 2018; Severová et al., 2021). Behind this vision is the belief that tourism should be an important part of promoting balanced development in the country, deconcentrating annual tourism demand from less developed regions and creating added value for local communities (Yfantidou, Matarazzo, 2017; Mathew, Sreejesh, 2017). As far as tourism is envisaged to help building a sustainable society, the preventive approach needs to become the part of all existing tourism policies and strategies (Yfantidou et al., 2017).

By identifying the key players in the mass tourism industry, tourism stakeholders and tourism policies can play a role in shaping strategies and measures that help tourism agents to make the right decisions to ensure environmental, cultural and economic sustainability.

This is also true even at the times of the COVID-19 pandemic when virtually all tourism industry came to a halt with international airlines and hotel chains experiencing huge losses (Hoque et al., 2020; Dvořák et al., 2020). The institutions of tourism experience a fundamental and unprecedented changes that are likely to shape up the economic and institutional development of this industry for decades to come.

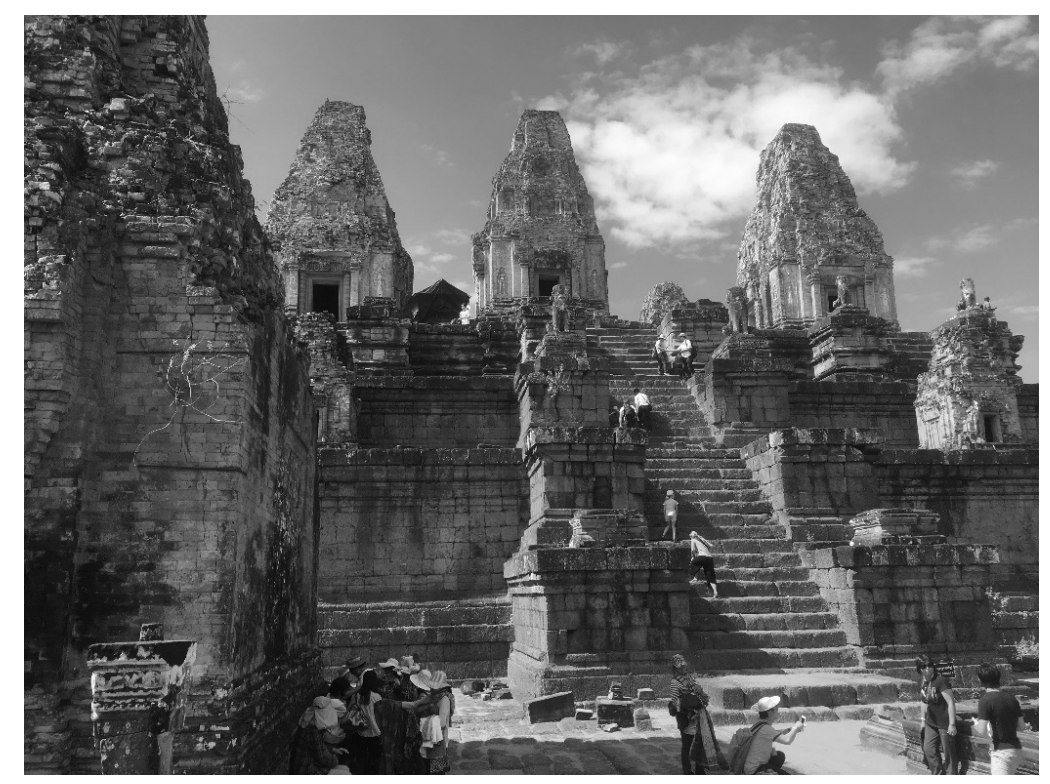

Fig. 1. Example of mass tourism: Angkor Wat, Siem Reap, Cambodia

Source: Authors.

Therefore, it might be very likely that after the coronavirus pandemic international tourism will never be the same. Such issues as mass tourism or overtourism (see Fig. 1) have long troubled the tourism industry, so, quite ironically, COVID-19 gave it a chance to take a pause and think over the new strategies for the future (De Luca et al., 2020; Higgins-Desbiolles, 2020).

Responsible tourism practices need to be based on learning from the previous flaws in order to avoid future mistakes. This leadership role can be used to build and foster sustainability approaches among consumers and households (Rausser et al.,2018) and the development of sustainable tourism strategies at all levels (Mihalic, 2020). Rather than regarding size as a menacing trait, the role and the business strategy of the large tour operators needs to be revised in order for them to become an opening wedge in the way of sustainable tourism.

Of course, mass tourism will not disappear or expand after the COVID-19 pandemic, but it will be considered the reality of our time and for some time will be taken for granted (Job et al., 2017; Megahed, Ghoneim, 2020). For this reason, a major challenge for sustainable tourism is to find a strong preventive approach that includes tourist activities, large or small (Radovic et al., 2017). There is a need to facilitate the dissemination of attitudes across the tourism industry. According to some 
studies, tour operators used their services to demonstrate their ability to influence a large number of customers. It is important to elicit the attitude of tourists towards the tourism sector as well as towards the industry as a whole (Chiabai et al., 2014; Romero et al., 2020; Troshin et al., 2002). It is a fact that we believe in the importance of sustainable tourism for the long-term development of the region as a whole (Ágh et al., 2021).

This paper focuses on the institutional and economic changes of tourism and sustainable development. It demonstrates that sustainable tourism can meet the needs of the current tourism industry while protecting the environment, generating future opportunities, as well as taking into account the long-term impact of tourism on local communities and the local and international economy.

\section{Environmental impacts of tourism on regions}

It is quite apparent that tourism and the environment are linked because tourism depends on natural resources for its survival (Musavengane, Kloppers, 2020; González-Torres et al., 2021). The negative and positive effects on tourism and the environment can be easily estimated. In fact, there are a number of studies that have identified both positive and negative environmental impacts of tourism. On the negative impact of tourism, it can be noted that poorly planned tourism development often leads to increased environmental stress, such as loss of natural resources and biodiversity degradation (Wassie, 2020). Another crucial issue of tourism impact might be the problems that arise due to the lack of involvement of the local citizens and dwellers, which leads to the issue of distrust and missing support (Strielkowski et al., 2016; Cristiano, Gonella, 2020).

Travel has been of great interest to people since the dawn of civilisation, and the tourism industry is now one of the fastest growing industries in the world, growing at an impressive annual rate (before the COVID-19 pandemic happened). Recently, it has been found that there is a strong correlation between the growth of tourism and environmental impacts such as loss of natural resources and biodiversity (Kim et al., 2020). Some destinations have taken this further and introduced restrictions on the number of tourists who can travel there at any time, and we are seeing more and more examples of this around the world. For example, the island of Borocay in the Philippines has been closed to tourists for two years in order to recover from the negative environmental effects of tourism in recent years (Canoy et al., 2020). A famous art festival Burning Man held in the magnificent Black Rock desert in Nevada, United States also limits the number of attendees (Strielkowski, 2018) since it introduced a lottery system to obtain the tickets for the event (Fig. 2).

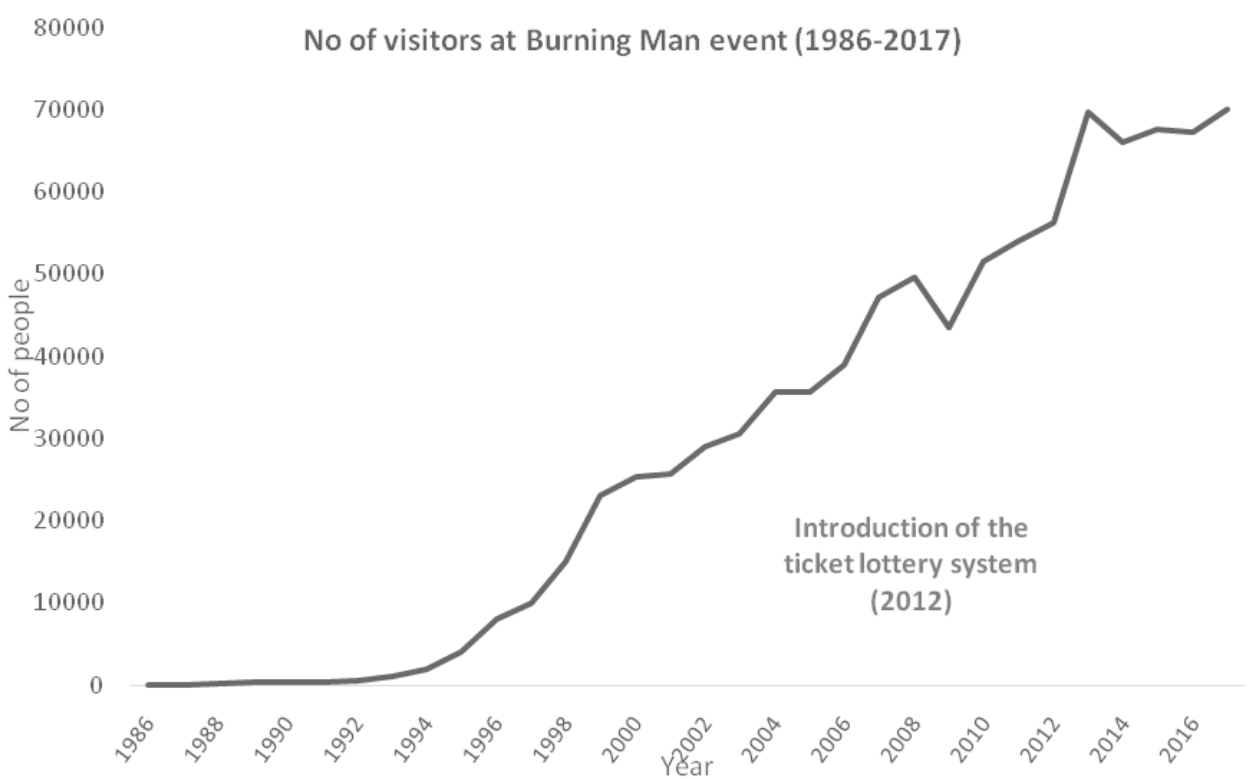

Fig. 2. Limiting the number of participants at Burning Man

Source: Burning Man Project. www.burningman.org - accessed October 312021. 
These are some positive examples of environmental tourism management for tourists who want to travel to the protected or fragile destinations. The negative environmental effects of tourism occur when the rate of use of the visitors is greater than the ability of the environment to cope with this use. Many tourist destinations are nature reserves, and too many visitors can destroy natural wonders. The environment is also negatively affected, as many of these trips require carbon dioxide and fossil fuels. Among many other reasons, measuring the impact of tourism is indeed one of the most important factors for successful and sustainable tourism development. Tourism generates various kinds of income that can contribute to the welfare of the host country, but its development negatively exploits natural resources, culture and local populations (Grilli et al., 2021; Simionescu et al., 2020; Zheng et al., 2020).

It is important to measure the environmental impact of tourism on the development of the whole industry, since it can help to foster nature conservation, albeit with a varying degree of success. Thence, social, economic, sustainable, and cultural impacts of tourism need to be taken into account. Jobs are created in sectors directly and indirectly linked to tourism, such as tourism management, tourism training and development of tourism infrastructure and services. Over the recent pre-pandemic years, the number of international tourists has increased from 25 million in 1950 to 1.4 billion annually, and that, too, is only international arrivals (Bak, Szczecinska, 2020). This does not take into account tourists travelling from country to country, whether short or long-haul. Even if we limit the numbers of visitors, little can be done, because the benefits that tourism brings to a country in terms of wealth are so great that environmental impact is often secondary. The activities that tourists participate in are constantly changing, from hiking and sightseeing to diving, 4x4 vehicles, and water sports. This makes it difficult for tourists and travellers to get to certain destinations, but it is also more expensive.

Meanwhile, there is also ecotourism, a part of sustainable tourism that often has ecological tendencies and can play an important role in protecting the environment and developing people's environmental culture. While all these factors are important for the promotion of the tourism industry, other factors must be taken into account in order to influence the industry. This is a good example of when to plan and manage tourism industry travel properly and when not. Investing in sustainable tourism options can therefore create a framework that can help protect the environment and strengthen the tourism industry at global level. Since we want to examine the environmental impact of international tourism, we have to recognize that international travel, particularly in the form of tourism, has a large number of positive effects on our environment. At the same time, tourism can also put enormous strain on local land use and cause environmental destruction. It can lead to increased pollution, loss of biodiversity and endangered species, and over time to a significant increase in the use of fossil fuels such as coal, oil and gas. Like any business, tourism can have a positive or negative impact on communities. The social and cultural impact of tourism can lead to the loss of livelihoods, as well as the destruction of natural resources. Many of these impacts are related to the construction industry, tourist facilities such as hotels, restaurants, tourist attractions, and other tourist facilities in many areas all around the globe.

\section{Economic and institutional indicators of sustainable tourism}

Measuring the impact of tourism on environmental indicators can be helpful for sustainable tourism planning, especially if the strategy is designed to achieve the positive side of the indicators. Many tourist facilities produce relatively high amounts of waste compared to local waste. A well-implemented waste management strategy can prevent a number of environmental problems, such as air pollution, water pollution and waste management. There are some agencies and consultancies which have a deep understanding of indicators, measurement and practice and have worked with a number of clients including the United Nations, the European Union and the World Health Organization (WH0). The work of hundreds of authors mobilises the knowledge and expertise of the international community to address key issues used by indicators and to identify best practices such as, for example, the Sustainable Tourism Indicators for Sustainability of Tourism (STTI) (Rasoolimanesh et al., 
2020). In other destinations and regions of the world, new workshops on indicators are planned to integrate new programmes to establish sustainable tourism observatories at the target level. Indicators for the development and implementation of the Sustainable Tourism Indicator for Sustainability of Tourism can be used to measure the degree of sustainability in tourism. There are some initiatives to develop and implement the Sustainable Tourism Sustainability Indicator at target level.

Effective governance and implementation of sustainable tourism also generally requires evidence-based decisions to be presented, backed up by clear indicators. In order to develop and implement sustainability indicators for tourism effectively, the objectives need to be given new opportunities by actors who may previously have been excluded from the political process. As the frequency of topics discussed in the articles cited above shows, tourism indicators related to the sustainability of tourism and its impact on the environment and human health have been examined in a variety of contexts. However, given the importance that participatory approaches to tourism planning are often attached to, and the lack of transparency and accountability, surprisingly little attention has been paid to the dimension of governance.

One can agree that tourism does not take place in an isolated social vacuum. It affects the social and environmental fabric of a place and, if not deliberately managed, only leads to an extension of systemic problems that are felt in communities, regions and countries (Khoshnava et al., 2019). The key to a thriving tourism industry is to address how tourism can benefit communities by increasing economic opportunity, supporting socio-cultural systems, and maintaining the healthy ecosystems on which they depend. Although there are many ways to understand success, this interpretation seems to be in stark contrast to those that help us to deliver our services and plan sustainability. The tourism industry focuses on how many tourists visit a destination, not on how much money is spent in a destination or how tourism impacts the environment. The empirical analysis shows that there is a strong correlation between the number of tourists and the sustainable development of the tourism industry. There are some countries that have great potential for tourism development and that steps need to be taken to increase ecological and cultural sustainability, develop infrastructure, and increase competitiveness.

Monitoring is the process of regularly measuring something by using indicators to provide an accurate picture of the health and sustainability of an area, such as the quality of air, water, soil and water. Indicators help simplify complex information by selecting and measuring an element as an indicator of the state of a given problem. In addition, these indicators are characteristic figures that show the change in a state or its criteria. The criteria describe the quality of air, water, soil and water in an area and the number of tourists, and tourists in the area.

\section{Digitalization and promotion of regional tourism potential}

The influence of globalisation on tourism is an important factor in the popularity of leisure activities, sights and cultures that are visited around the world. While acts of terrorism cannot be stopped, the tourism industry is trying to provide as much information as possible about what can be achieved by promoting and popularizing its destinations (Palazzo et al., 2021). Generating knowledge about a destination is obviously an important first step in marketing.

Competition for visitors is fierce, given the sheer number of destinations available, and it can be easy to get lost in the noise of global competition. Of course, tourism and event management can exist separately, but consolidating them can bring many benefits to the tourism industry in terms of marketing, promotion and public relations. This was made possible because tourists travel around the world in search of new impressions and emotions.

Let us see an example from India where the India Tourism Development Corporation remains a leading force in tourism development. In the 1950s, tourism was recognised as one of the most important sectors of India's economic development plan. In 1966, the India Tourism Development Corporation was founded to promote India as a tourist destination. Tourism development was taken up by the government in a series of five-year plans and picked up steam with the establishment of a Tourism Finance Corporation to finance tourism projects. In 1988, the Indian government presented 
a plan to achieve the full potential of tourism, followed in 1992 by the National Plan for the Development of Tourism in India (NDPI) (Venugopalan, 2019).

The India Tourism Development Corporation and its subsidiaries play a marketing and advisory role. They train tourism and hotel professionals, manage the development of tourism infrastructure such as restaurants, hotels and resorts, and manage the tourism industry. The Ministry of Tourism of India also cooperates with the Institute of Skiing and Mountaineering.

Additionally, there are some novel and emerging forms of tourism. Although war tourism is not a new phenomenon, the increasing commercialization has shaped the new trend. Dark tourism has its roots in the days when Thomas Cook took visitors to hang out. The growth of technology and interpersonal communication has led to a faster growth in this area of tourism (Strielkowski, Kasl Kollmannová, 2014; Mitsche, Strielkowski, 2016; Tussyadiah, 2020). This phenomenon can be seen as a contributing factor, but information and publicity contribute significantly to this objective (Korneeva et al., 2021), so do the new technologies, such as, for example, 5G networks (Strielkowski et al., 2021b). This will attract more tourists who want to see and enjoy new and interesting places in the region. If achieved, it will lead to sustainable development, which will be reflected in the number of tourists visiting cross-border regions. Creating tourist products and services should be based on the natural and cultural heritage and carrying out research and development of tourist infrastructure and development in the regions of the country. Introduction of a theme-based tourist tours can also foster both mass and niche tourism.

Going back to the Indian example again, one should note that the tourism and hospitality sector are widely recognized as one of the most profitable sectors in the country, with a gross domestic product (GDP) of over $\$ 1.5$ billion. According to the benchmarking of the World Tourism Organization (WT0), the tourism sector in India alone generates a GDP of around 1.3 million dollars (Sahoo, Ashwani, 2020). This is why it is important to develop Indian infrastructure with a goal of promoting their cultural heritage and values while increasing the attractiveness of tourism. The introduction of internationally recognized standards in the field of sustainable tourism and tourism management can help companies understand the practical aspects of sustainability in tourism and help them to mobilise investment.

In order to make a comparison, one can find out that tourism generates more than $\$ 1.5$ billion in economic activity annually in Africa and the Middle East (Streimikiene, Korneeva, 2020). The same estimate expects India to boost the growth of India's tourism industry, playing an important role in the economies of these countries. India's share of global tourist arrivals is higher than that of other countries such as the United States, Canada, Australia, and New Zealand. The growth of these new destinations will affect Indian economy as it struggles to account for a share of the growing tourism industry (Irani et al., 2021). Its many unique cultures and experiences will help keep the province competitive while the industry also recognizes the potential negative impact of tourism on the economy. Moreover, it will further strengthen its ability to generate economic growth, jobs, tourism revenues and economic activity (Farinha et al., 2021).

Thence, the key to the long-term survival of the tourism industry is to promote and popularize local tourism potential and its unique culture and experience (Kar et al., 2020; Fedorchenko et al., 2021). According to a report by the Indian Tourism Development Authority, central and regional government agencies should plan and implement tourism development without hindering these efforts ${ }^{1}$. All of the above experiences might become an inspiration for the other countries seeking to foster and promote the development of their sustainable regional tourism.

\section{Burning Man festival: An example of sustainable tourism that went digital}

Burning Man is known as probably the most famous art festival in the world. For many years now, it used to take place every year around Labor Day (that was before the COVID-19 pandemic) and last for one week in U.S. Nevada's Black Rock Desert, a protected area. As Brill ${ }^{2}$ describes, Burning Man

Simm C. (2018). USA today. https://traveltips.usatoday.com/tourist-destinations-development-tourism-india-100439.html - accessed November 202021

Brill L. (2018). The first year in the desert. http://burningman.org/culture/history/brc-history/event-archives/1986-1991/firstyears accessed November 10202 
started as a bonfire ritual for a small group of friends but has evolved into one of the most popular art festivals in the world. Since the festival moved to the Nevada desert in 1996, thousands of people come to build the Black Rock city, a town that appears as an official settlement on the Nevada state records and officially exists for about 10 days each year. As Strielkowski (2018) points out, many visitors refer to Burning Man as a "magic circus in the desert" for its unique atmosphere (Strielkowski, 2017).

There are various forms of art installations, mutant vehicles, music and art performances, or bars and cafes which practice "free gifting" all centered around the gigantic wooden figure of "The Man", the festival's mascot. Most of the art installations have to be assembled in the Black Rock Desert months before the Burning Man event and the majority of them is burnt at the end of the festival. Nowadays, the Burning Man festival attracts over 60,000 people (the number has grown from 50,000 in 2011 to 65,000 in 2014) each year and annually yields over $\$ 8,000,000$ USD (Fig. 3 ) in tickets and contributions (Strielkowski, 2018).

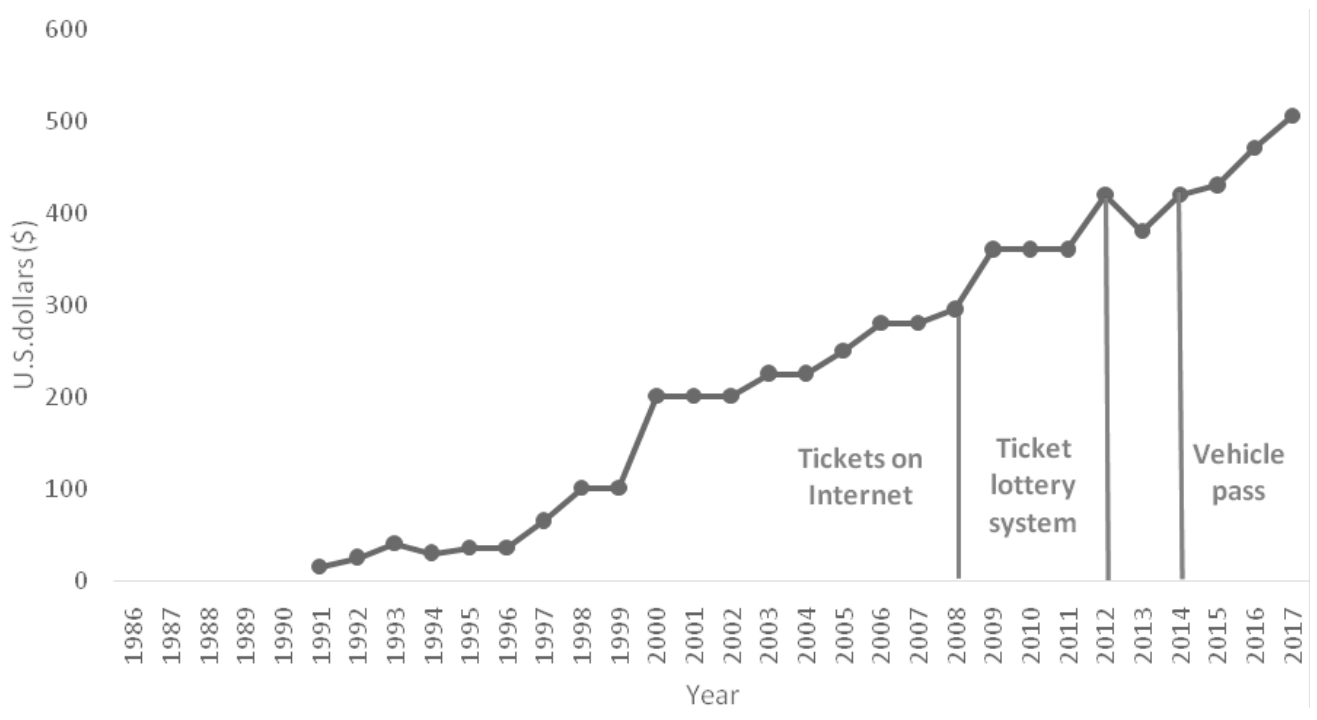

Fig. 3. The price of Burning Man ticket (1991-2017)

Source: Burning Man Project. www.burningman.org - accessed October 312021.

Burning Man has become a cultural phenomenon with many researchers studying its social, cultural, as well as economic implications (see Gilmore and Van Proyen, 2005; Chen, 2009; Turner, 2009). Some aspects of Burning Man, such as nudity, radical self-expression, or exhibitionism are criticized both in the research literature and mass media, however prior to COVID-19 pandemic the event attracted many celebrities including Sergey Brin and Larry Page of Google, Paris Hilton, or Elon Musk, just to name a few. Figure 4 that follows shows the photograph with figure of Man took by one of the authors of this paper at the Burning Man festival in 2017.

The first Burning Man festival was first held in 1986 on Bakers Beach in San Francisco. However, following interference by the park police in 1990 with the aim of stopping the burning of the statue, the Burning Man event shifted its location, date, and meaning. During the time, it was majorly a gathering involving a group of friends that took place during the summer solstice and was organized by Larry Harvey, Jerry James and a few other friends (Burning Man, 2021).

This event has continued taking place annually between the last Sundays of August to the first Monday in September. During this gathering, the friends burned a nine-foot wooden man and a smaller wooden dog. Larry described the action of burning these objects as a spontaneous act of radical self-expression (Doherty, 2006).

However, prior to 1986, Mary Grauberger who was a friend of Larry's girlfriend, Janet Lohr, used to hold solstice gatherings on Baker Beach each year prior to 1986, some of which were attended by Larry. It is only after Grauberger stopped holding the gatherings that Larry Harvey took the initiative of organizing the events himself (Doherty, 2006). During the afternoon of June 21, 1986, Larry 
and Jerry James took the initiative to build the first wooden effigy by using scrap wood which would later be burned that evening.

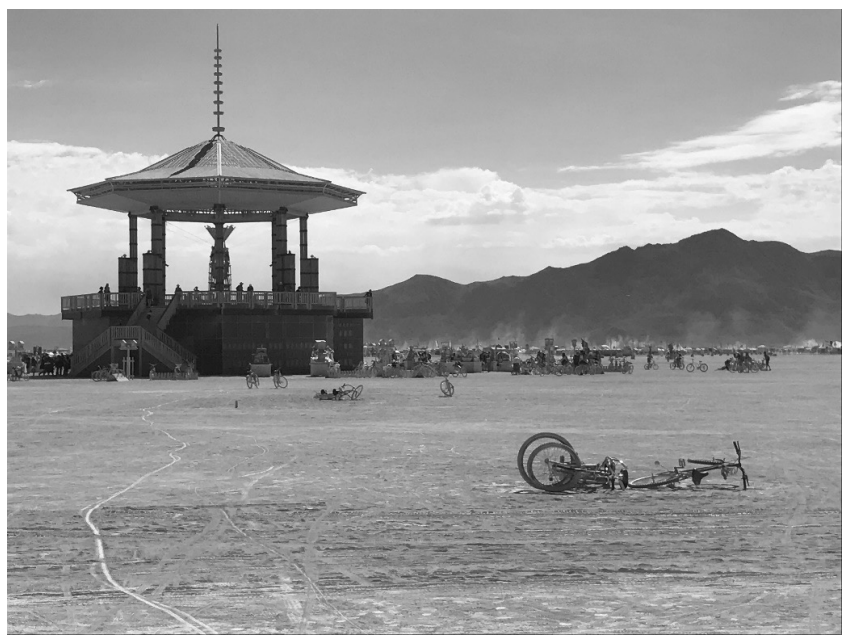

Fig. 4. The figure of Man at the Burning Man festival (2017), Black Rock desert, NV Source: Authors.
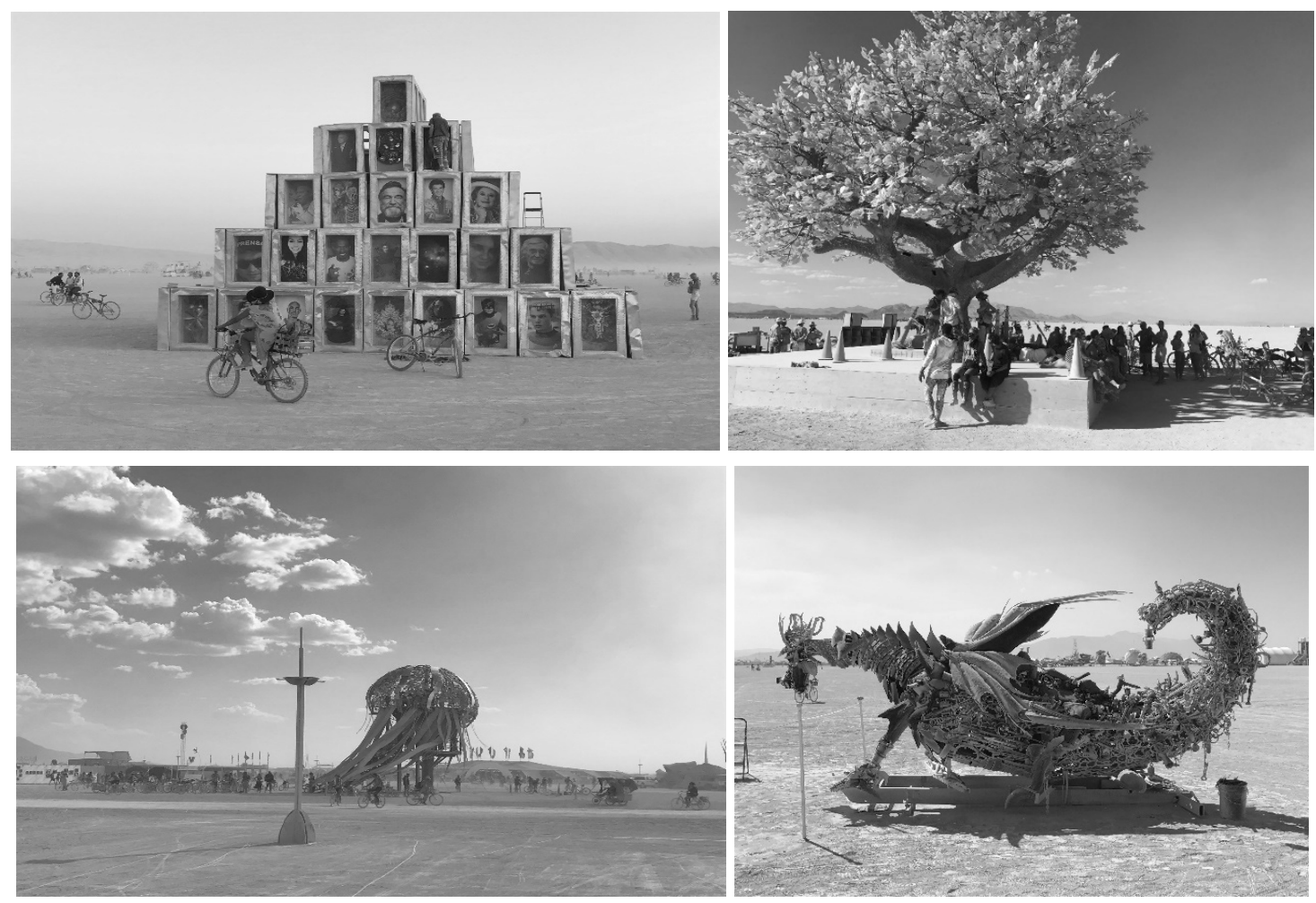

Fig. 5. Art installations and Central Camp at the Burning Man festival (2017), Black Rock desert, NV Source: Authors.

As the years advanced the effigy grew bigger and bigger. In 1987, the wooden man was fifteen feet tall and later in 1988, it had been increased to around 40 feet tall during which they formally named the ceremony Burning Man ${ }^{3}$.

Each year, a different theme from the previous year's celebration is created. In 2006, the established theme was Hope and Fear while in 2007, the theme was The Green Man. In 2011, the theme was changed to Rites of Passage, while in 2012 it was Fertility 2.0.

\footnotetext{
${ }^{3}$ Burning Man Project. www.burningman.org - accessed October 312021
} 
These changing themes often establish the design by which The Man is based upon to some extent. Despite the fact that The Man's design and method of construction has relatively remained the same throughout the years since its formal launch, the structure on which he stands is greatly affected by that year's theme. These themes are also adopted by the participating artists in their artworks, costumes, camps and vehicles. The most commonly incorporated forms of art during the festival are outsider art and visionary art. During the ceremony, numerous theme camps are set up by organizers as well as residence centres set up by sub-communities of participants which often incorporate design and artistic elements in a bid to engage a large part of the community thus being in line with the interactivity requirements put forward by the organizers ${ }^{4}$. It is also common practice for music performances and guerrilla street theatre art forms to be incorporated within the various camps and developed areas of Black Rock City. Sculptures containing kinetic, electronic and fire elements are also a common site on areas adjacent to the city where isolated artworks are displayed. These artworks are normally the work of artists utilizing resources available to them.

However, the Burning Man community's Art Department usually offers artists grants to cover part of their costs. Artists seeking these grants are normally required to apply for them early in advance. These artworks must be in accordance with the themes and interactivity of the event for them to be eligible for the grant. Included among the artworks are the mutant vehicles, decorated mountain bikes temples which may be ritually burned later on after the burning of the Man (see Fig. 5).

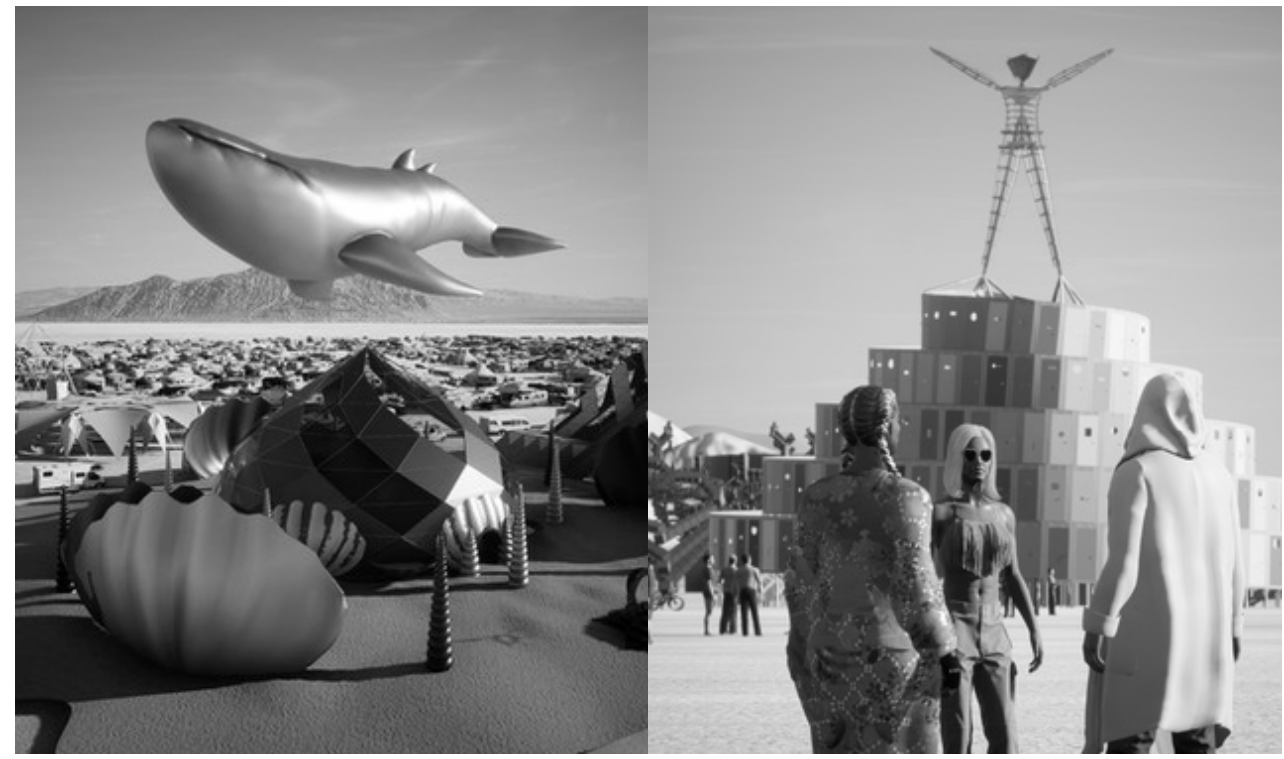

Fig. 6. Screenshots from the Multiverse app, digital Burning Man festival (2021)

Source: Multiverse (2021). Multiverse: interactive immersive reality. https://dustymultiverse.com - accessed November 012021.

Unfortunately, the Burning Man festival was suspended in 2020 due to the COVID-19 pandemic. The event was cancelled for two years in a row but it has been replaced by the "digital Burning Man" and "immersive experience" that attempts to keep the Burners community together using online content that features elements of virtual reality, online gaming (apparently, video games have an effect on emotional creativity (Č́ablková et al., 2020) and augmented reality offered via apps and digital tools (see Fig. 6). This represents a good example of how sustainable tourism can operate in the digital age even in the times of the crisis such as the one represented by the COVID-19 pandemic of 2020-2021.

\section{Non-market valuation of demand for the Burning Man festival: A travel cost method}

In this empirical part of our paper, we evaluate the non-market valuation of demand for the Burning Man festival using the travel cost method (TCM). In order to do so, we employ the following non-parametric tests: Chi-squared $(\chi 2)$ for nominal x nominal variables tests, Mann Whitney (U) for ordinal x nominal (2 groups)

\footnotetext{
4 May M. (2005). Theme camps. http://www.sfgate.com/cgi-bin/article.cgi?f=/c/a/2005/08/31/BAGD0EFM9G1.DTL-accessed September 102021
} 
variables test; Kruskal-Wallis $(\mathrm{H})$ for ordinal x nominal (3+ groups); t-test for ratio x nominal (2+ groups); F-test for ratio $\mathrm{x}$ nominal (3+ groups); and Person correlation ( $\mathrm{r}$ ) for ratio $\mathrm{x}$ ratio variables tests. The purpose of applying these tests is related to the detection of possible significant differences between U.S. citizens and other nationals regarding the travel and participation costs associated with Burning Man festival.

The analysis that follows, uses the unique data set obtained from the questionnaire survey conducted at the Burning Man 2017 "Radical Ritual" event by one of the co-authors of the paper, an experienced Burner.

The questionnaire contained questions dealing with various economic and demographic characteristics of Burning Man participants, e.g.: information on age, gender, nationality, education, occupation of each household member, total monthly net household income, times of attending Burning Man, ticket costs and other expenses, etc. The survey consisted of two parts but not all questions were used explicitly in econometric models presented further in this paper. Our samples contained $35 \%$ females and $65 \%$ males. The average age was 32 years. $63 \%$ of the respondents were single and $83 \%$ childless. $50 \%$ of the respondents had a Bachelor or Master degree or a post-graduate degree.

As it is usual among data samples that are based on questionnaire survey, there are several limitations. However, it appears that our own data set has some advantages over the official Burning Man data sets (e.g. Burning Man Census) collected on the macro level, since questionnaire detects personal characteristics and other information relevant for our empirical model. In addition, we can study the patterns and motivations of the participants at the micro level.

\begin{tabular}{|r|r|r|}
\hline nation y & Obs & Rank Sum \\
\hline 1 & 137 & 14146.00 \\
2 & 97 & 13349.00 \\
\hline
\end{tabular}

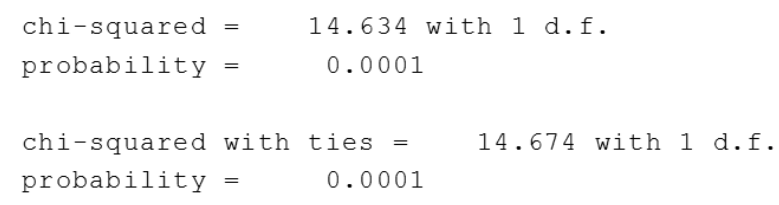

Fig. 7. Kruskal-Wallis test: cost of transport

Source: 0wn results.

The data collection was carried out in a form or a stratified random sample that included random selection of sectors at Black Rock City with consecutive selection of respondents to be approached. In total, we managed to obtain a valid sample of 251 surveys. Despite above mentioned limitations, our sample yields interesting results.

According to Kruskal-Wallis test (Fig. 7 above), there are significant differences between Americans and people of other nationalities regarding the cost of transport from their place of residence to the location of the Burning Man festival (Black Rock desert in Nevada).

\begin{tabular}{|r|r|r|}
\hline nation y & Obs & Rank Sum \\
\hline 1 & 130 & 14485.00 \\
2 & 93 & 10491.00 \\
\hline
\end{tabular}

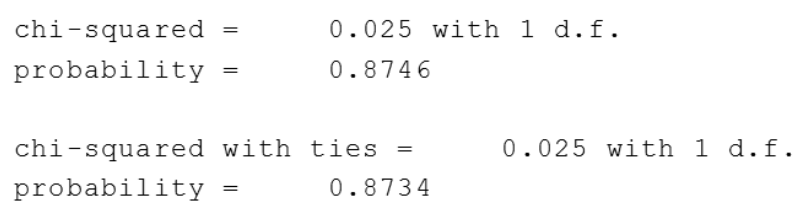

Fig. 8. Kruskal-Wallis test: ticket price

Source: 0wn results. 
According to Kruskal-Wallis test, there are no significant differences between Americans and other countries nationals with regard to the price of the ticket for the Burning Man festival (Fig. 8).

\begin{tabular}{|r|r|r|}
\hline nation y & Obs & Rank Sum \\
\hline 1 & 67 & 3874.50 \\
2 & 51 & 3146.50 \\
\hline
\end{tabular}

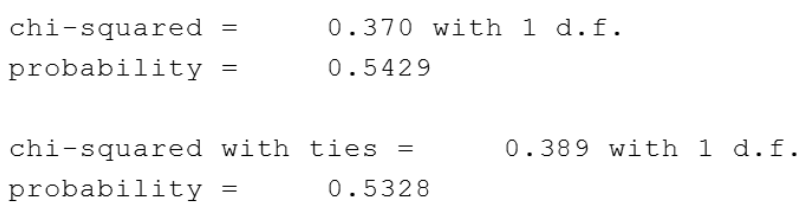

Fig. 9. Kruskal-Wallis test: paid price

Source: 0wn results.

\begin{tabular}{|c|c|c|c|c|c|c|c|}
\hline Iteration 0 : & log likelihood & $=-151.32768$ & & & & & \\
\hline Iteration 1: & log likelihood & $=-149 \cdot 39811$ & & & & & \\
\hline Iteration 2: & log likelihood & $=-149 \cdot 39127$ & & & & & \\
\hline Iteration 3: & log likelihood & $=-149.39127$ & & & & & \\
\hline Logistic regress & sion & & & Number of & obs & $=$ & 251 \\
\hline & & & & LR chi2(1 & & $=$ & 3.87 \\
\hline Log likelihood $=$ & $=-149.39127$ & & & Pseudo R2 & & $=$ & $\begin{array}{l}0.0491 \\
0.0128\end{array}$ \\
\hline other_festival & Coef. & Std. Err. & $\mathrm{z}$ & $P>|z|$ & {$[95 \%$} & Conf. & Interval] \\
\hline attended_before & .5552774 & .2850455 & 1.95 & 0.051 & -.0034 & 4015 & 1.113956 \\
\hline cons & -1.203973 & .2194269 & -5.49 & 0.000 & -1.634 & 4042 & -.7739041 \\
\hline
\end{tabular}

Fig. 10. Results of the binary logistic regression model

Source: 0wn results.

In case of the respondents who agree to pay an extra amount towards additional Black Rock Desert preservation and infrastructure development, there are not significant differences between Americans and people of other nationalities regarding the sum of money they were willing to pay (Fig. 9).

More binary logistic regression models were run, considering the participation at another (similar or vaguely similar) festival(s): the dependent variable we used assumed the value of 0 (participation only in Burning Man) and 1 (participation in another festival).

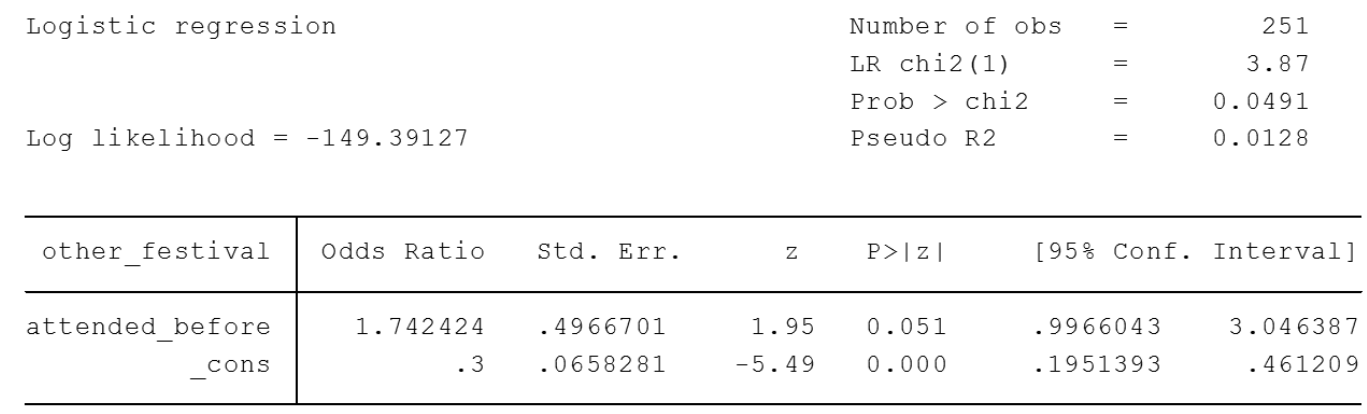

Source: 0wn results.

Fig. 11. Results of the binary logistic regression model 
The results of binary logistic regression indicated that people who attended the Burning Man festival in the past (one of several times) have, in average, higher chances to attend another festival. The chances to attend another festival for a person that attended the Burning Man festival before are with $74.24 \%$ higher than in a case of a person that came to Burning Man for the first time in 2017 (Fig. 10 and 11).

In addition to the models tested above, we can also employ the Poisson model. The Poisson probability density distribution function can be expressed as follows:

$$
\operatorname{Prob}(Y=k)=\left(\exp ^{(-\lambda)} \lambda^{k} / k !\right), k=0,1,2, \ldots, \infty
$$

where $Y$ is the number of trips to Burning Man festival in the past years and $\lambda$ is the mean and the variance of the distribution (the expected number of trips).

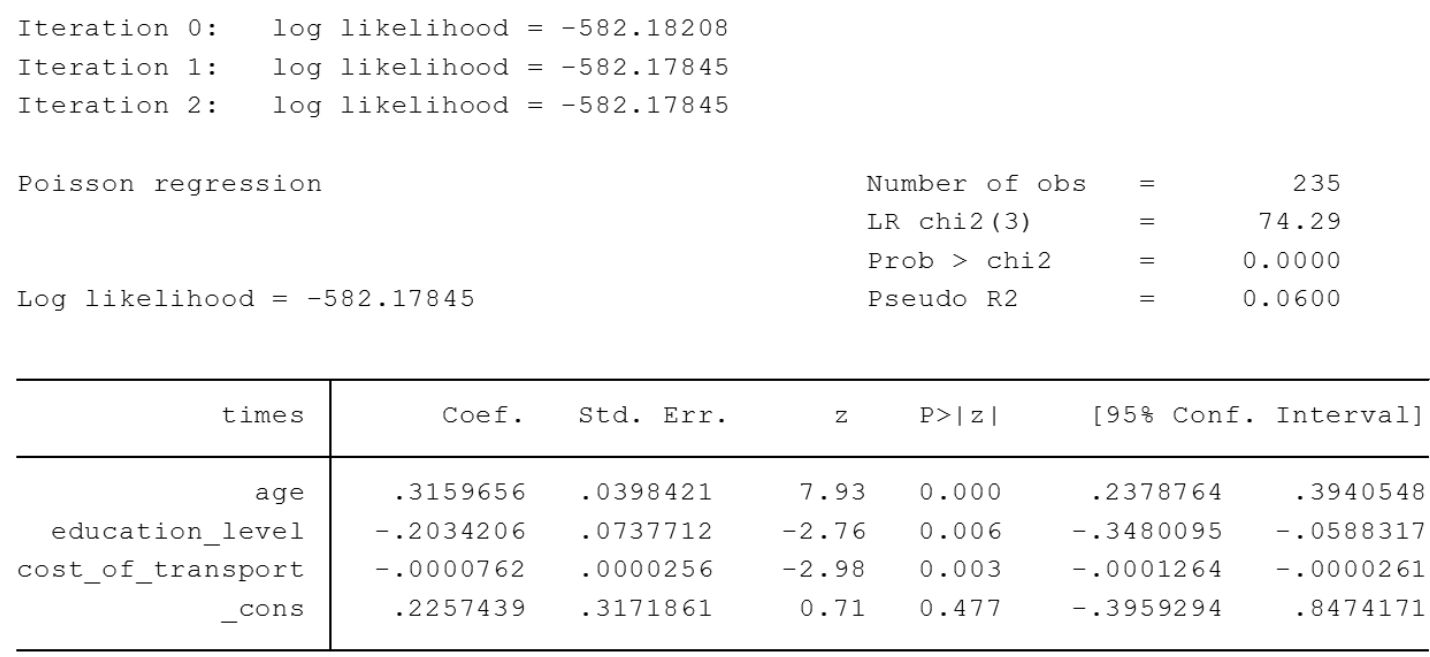

Source: 0wn results.

Fig. 12. Results of Poisson model

More Poisson, negative binomial and mixed-effects generalized linear models were constructed in order to explain the number of times the people attended the Burning Man festival before 2017.

\begin{tabular}{|c|c|c|c|c|c|c|}
\hline Iteration 0 : 10 & g likelihood = & -582.18208 & & & & \\
\hline Iteration 1: & g likelihood = & -582.17845 & & & & \\
\hline Iteration 2: & g likelihood = & -582.17845 & & & & \\
\hline Poisson regressio & & & & Number of obs & $=$ & 235 \\
\hline & & & & LR chi2(3) & $=$ & 74.29 \\
\hline & & & & Prob > chi2 & $=$ & 0.0000 \\
\hline Log likelihood $=$ & -582.17845 & & & Pseudo R2 & $=$ & 0.0600 \\
\hline times & IRR & Std. Err. & z & $\mathrm{P}>|z|$ & [95\% Conf. & - Interval] \\
\hline age & 1.371583 & .0546468 & 7.93 & 0.000 & 1.268552 & 1.482982 \\
\hline education_level & .815935 & .0601925 & -2.76 & 0.006 & .7060922 & .9428654 \\
\hline cost_of_transport & .9999238 & .0000256 & -2.98 & 0.003 & .9998737 & .9999739 \\
\hline _cons & 1.253255 & .3975149 & 0.71 & 0.477 & .6730542 & 2.333612 \\
\hline
\end{tabular}

Source: 0wn results.

Fig. 13. Results of Poisson model 
According to the Poisson model (Fig. 12 and 13), the age was positively correlated with the number of attendances of Burning Man in the past, while the cost of transport and level of education had a negative impact on the number of previous visits. An additional increase in age by 1 year increases the number of attendances, on average, by 1.37 times compared to the previous year.

If the cost of transport increases, the people are less eager to attend Burning Man festival. If the cost of transport increases just by 1 dollar, the number of attendances decreases, on average, by around 19\% compared to the situation when the cost remains the same. All in all, it appears that people with higher education are less motivated to come to Burning Man festival compared to those with lower education.

\begin{tabular}{|c|c|c|c|c|c|c|c|}
\hline Negative binol & ial regressi & & & Number & of obs & $\begin{array}{l}= \\
=\end{array}$ & $\begin{array}{r}224 \\
21 \quad 05\end{array}$ \\
\hline Dispersion & $=$ mean & & & Prob > & chi2 & $=$ & 0.0000 \\
\hline Log likelihoo & $=-404.074$ & & & Pseudo & R2 & $=$ & 0.0254 \\
\hline times & Coef. & Std. Err. & z & $\mathrm{P}>|z|$ & {$[95 \%$} & Conf. & Interval] \\
\hline age & .4447984 & .1170452 & 3.80 & 0.000 & .2153 & 3939 & .6742029 \\
\hline price_ticket & -.0010995 & .0004143 & -2.65 & 0.008 & -.0019 & 9115 & -.0002875 \\
\hline _cons & -.6671506 & .5133266 & -1.30 & 0.194 & -1.673 & 3252 & .338951 \\
\hline /lnalpha & .6634388 & .1578588 & & & .3540 & 413 & .9728363 \\
\hline alpha & 1.941457 & .306476 & & & 1.424 & 814 & 2.645437 \\
\hline
\end{tabular}

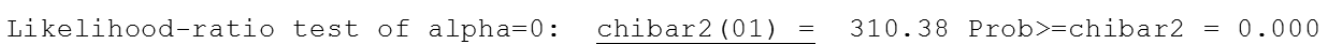

Source: 0wn results.

Fig. 14. Results of the negative binomial regression

According to the negative binomial model, the number of attendances is again positively correlated with the age of the participant. Moreover, the price of the ticket is negatively correlated with the number of previous visits to Burning Man. At each increase in the age by 1 year, the person has a 56\% higher chance to visit Burning Man festival again. If the price of the tickets increases by 1 dollar, the probability of attending again Burning Man for the successive time(s) decreases by $1 \%$ compared to the situation when the price of the ticket remains the same (Fig. 14, 15).

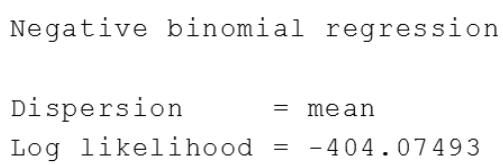

\begin{tabular}{r|rrrrrr}
\hline times & IRR & Std. Err. & $z$ & P $>|z|$ & [95\% Conf. Interval] \\
\hline age & 1.560176 & .1826111 & 3.80 & 0.000 & 1.24035 & 1.962468 \\
price_ticket & .9989011 & .0004139 & -2.65 & 0.008 & .9980903 & .9997126 \\
_cons & .5131687 & .2634231 & -1.30 & 0.194 & .1876358 & 1.403475 \\
\hline /Inalpha & .6634388 & .1578588 & & & .3540413 & .9728363 \\
\hline alpha & 1.941457 & .306476 & & & 1.424814 & 2.645437 \\
\hline
\end{tabular}

Likelihood-ratio test of alpha=0: $\operatorname{chibar2}(01)=310.38$ Prob $>=\operatorname{chibar2}=0.000$

Source: 0wn results.

Fig. 15. Results of the negative binomial regression 


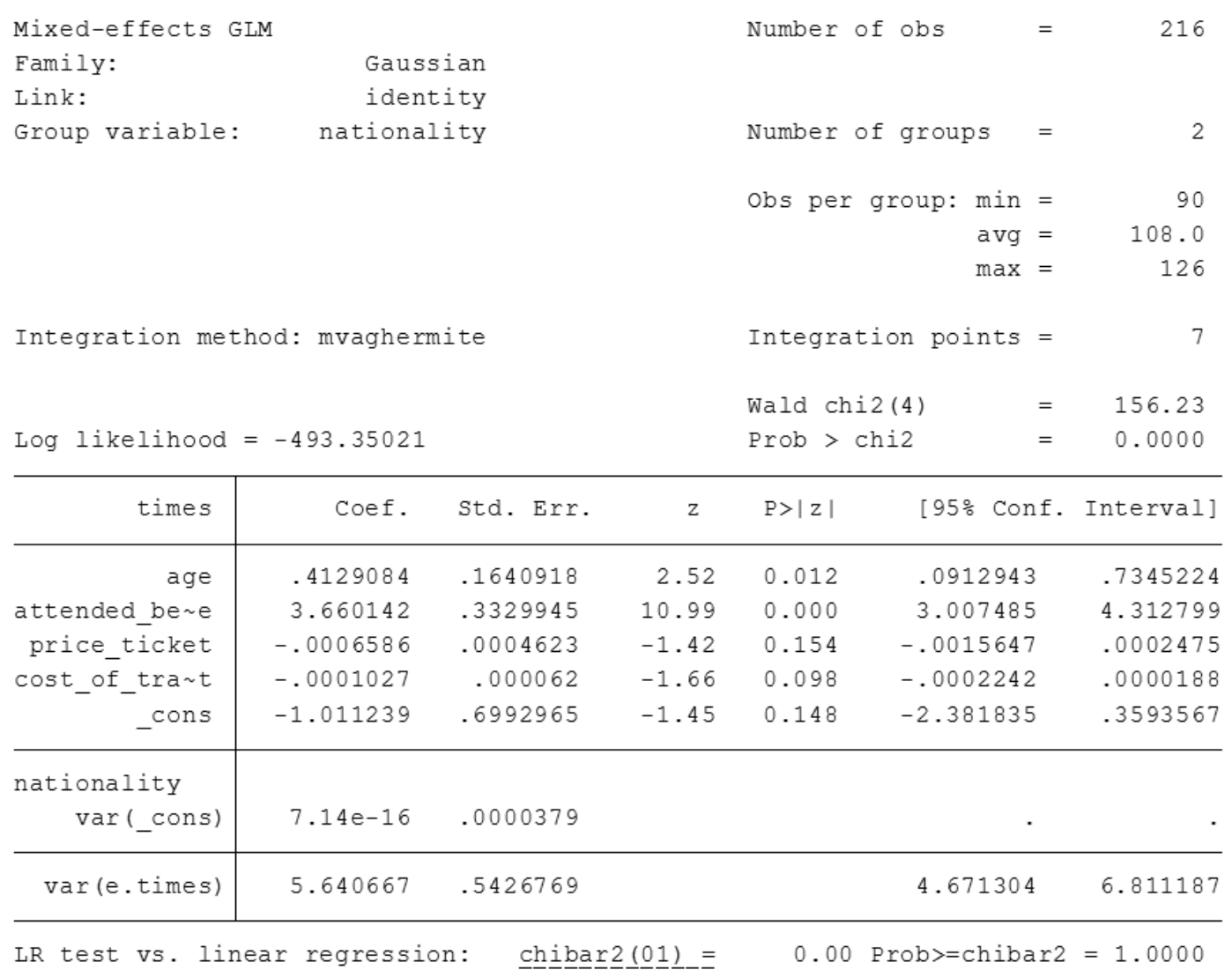

Source: 0wn results.

Fig. 16. Results of the mixed-effect generalized linear model

In addition, when it comes to the output from a mixed-effects generalized linear model that makes the distinction between Americans (U.S. citizens) and other nationalities, the number of attendances to Burning Man festival appear to depend only on the age of the participants, on their attendance of Burning Man before and on the cost of transportation (at 10\% level of significance). The price of the ticket does not have any significant impact on the decision of coming to Burning Man festival both for Americans and for people from other countries. The results of the mixed-effect generalized linear model that explains the number of visits to Burning Man festival are reported in Fig. 16 above.

\section{Conclusions}

Overall, our paper provided a concise review of some key concepts and sources and outlined the impact that the relationship between tourism and sustainable development can have. In addition, we tackled the issue of digitalization in the sustainable tourism. Furthermore, our research focused on promoting sustainability in tourism and its role as a means of economic and social development. Our research confirms, albeit mostly theoretically and using the available literature and sources, that in order for some countries to have greater potential in tourism and development, steps such as increasing environmental, cultural and sustainability and infrastructure development as well as competitiveness are needed.

The examples demonstrated in this paper clearly show that sustainable tourism approach can be of a great benefit for the sustainable regional development which is even more important now, almost a year into the COVID-19 pandemic that put a stop to massive international travel and tourism and might shape up the tourism industry in an entirely new way. Even though it is quite hard to predict what profound changes it will bring about to the tourism industry, some trends, such as the drastic reduction of business and conference travel, are traceable and foreseeable.

In addition, we used an example of Burning Man festival and employed the unique data set collected during the 2017 Burning Man event in order to compute an empirical model showing that im- 
portant and iconic sustainable tourism events would attract people regardless of any obstacles and price barriers. It is obvious that once the coronavirus restrictions are lifted, sustainable tourism is going to skyrocket all around the world. However, this time people are likely to be more cautious and sensitive to their environment. In addition, they are likely to use more digital tools and electronic services for facilitating their travels and making them more memorable.

All in all, it becomes clear that sustainable tourism is an important source of income for local communities which, if managed properly, can be a means of ensuring sustainable development. As a result of the diversification and fragmentation of social groups, the tourism market is growing increasingly segmented and heterogeneous. The development of tourism has raised awareness of the importance of sustainable tourism for the development and sustainability of local communities. This importance can be even reinforced by the use of ICT and Internet-based technologies that are changing the institutions of tourism and will forever alter its institutional and economic foundations.

\section{Литература / References}

Ágh P., Vavrek R., Dvořák M., Papcunová V. (2021). Economic evaluation of the management of municipal firms at the level of rural local self-governments (Case study). Economies 9(3): 130. https://doi.org/10.3390/economies9030130

Bak I., Szczecinska B. (2020). Global demographic trends and effects on tourism. European Research Studies 23(4): 571-585. https://doi.org/10.35808/ersj/1701

Č́ábelková I., Strielkowski W., Rybakova A., Molchanova A. (2020). Does playing video games increase emotional creativity? International journal of Environmental Research and Public Health 17(7). https://doi.org/10.3390/ijerph17072177

Canoy N., Roxas G., Robles A., Alingasa A., Ceperiano A. (2020). From cesspool to fortified paradise: analyzing news media territorial assemblages of rehabilitating Boracay Island, Western Philippines. Journal of Sustainable Tourism 28(8): 1138-1157. https://doi.org/10.1080/09669582.2020.1726934

Chen K. (2009). Enabling Creative Chaos: The Organization Behind the Burning Man Event. University of Chicago Press.

Chiaba A., Platt S., Strielkowski W. (2014). Eliciting users' preferences for cultural heritage and tourism-related e-services: a tale of three European cities. Tourism Economics 20(2): 263-277. https://doi.org/10.5367/te.2013.0290

Cristiano S., Gonella F. (2020). 'Kill Venice': A systems thinking conceptualisation of urban life, economy, and resilience in tourist cities. Humanities and Social Sciences Communications 7(1): 1-13. https://doi.org/10.1057/s41599-020-00640-6

De Luca G., Shirvani Dastgerdi A., Francini C., Liberatore G. (2020). Sustainable cultural heritage planning and management of overtourism in art cities: Lessons from atlas world heritage. Sustainability 12(9). https://doi.org/10.3390/su12093929

Doherty B. (2006). This Is Burning Man. Benbella Books.

Dvořák M., Rovný P., Grebennikova V., Faminskaya M. (2020). Economic impacts of COVID-19 on the labor market and human capital. Terra Economicus 18(4): 78-96. https://doi.org/10.18522/2073-6606-2020-18-4-78-96

Farinha F., Bienvenido-Huertas D., Duarte Pinheiro M., Silva E., Lança R., José Oliveira M., Batista R. (2021). Sustainable competitiveness of tourism in the Algarve Region. Critical stakeholders' perception of the supply sector. Sustainability 13(11). https://doi.org/10.3390/su13116072

Fedorchenko V., Kutuev P., Fedorchenko N., Vasilets 0. (2021). Tourism and education in formation of the human capital agency. Linguistics and Culture Review 5(S2): 246-258. https://doi. org/10.37028/lingcure.v5nS2.1343

Gilmore L., Van Proyen M. (eds.). (2005). AfterBurn: Reflections on Burning Man. UNM Press

González-Torres T., Rodríguez-Sánchez J., Pelechano-Barahona E. (2021). Managing relationships in the Tourism Supply Chain to overcome epidemic outbreaks: The case of COVID-19 and the 
hospitality industry in Spain. International Journal of Hospitality Management 92. https://doi. org/10.1016/j.ijhm.2020.102733

Grilli G., Tyllianakis E., Luisetti T., Ferrini S., Turner R. (2021). Prospective tourist preferences for sustainable tourism development in Small Island Developing States. Tourism Management 82: 104178. https://doi.org/10.1016/j.tourman.2020.104178

Higgins-Desbiolles F. (2020). The "war over tourism": Challenges to sustainable tourism in the tourism academy after COVID-19. Journal of Sustainable Tourism 29(4): 551-569. https://doi.or g/10.1080/09669582.2020.1803334

Hoque A., Shikha F., Hasanat M., Arif I., Hamid A. (2020). The effect of Coronavirus (COVID-19) in the tourism industry in China. Asian Journal of Multidisciplinary Studies 3(1): 52-58.

Irani F., Katircioglu S., Gokmenoglu K. (2021). Effects of business and finance conditions on tourism firms' financial performances: evidence from major tourist destinations. SAGE Open 11(3). https://doi.org/10.1177/21582440211040120

Jeyacheya J., Hampton M. (2020). Wishful thinking or wise policy? Theorising tourism-led inclusive growth: Supply chains and host communities. World Development 131. https://doi.org/10.1016/j. worlddev.2020.104960

Job H., Becken S., Lane B. (2017). Protected Areas in a neoliberal world and the role of tourism in supporting conservation and sustainable development: an assessment of strategic planning, zoning, impact monitoring, and tourism management at natural World Heritage Sites. Journal of Sustainable Tourism 25(12): 1697-1718. https://doi.org/10.1080/09669582.2017.1377432

Kar N., Basu A., Kundu M., Giri A. (2020). Urban heritage tourism in Chandernagore, India: revival of shared Indo-French Legacy. GeoJournal. https://doi.org/10.1007/s10708-020-10328-8

Khoshnava S., Rostami R., Zin R., Štreimikienè D., Yousefpour A., Strielkowski W., Mardani A. (2019). Aligning the criteria of green economy (GE) and sustainable development goals (SDGs) to implement sustainable development. Sustainability 11(17): 4615. https://doi.org/10.3390/su11174615

Kim Y., Lee D., Kim C. (2020). Spatial tradeoff between biodiversity and nature-based tourism: Considering mobile phone-driven visitation pattern. Global Ecology and Conservation 21. https:// doi.org/10.1016/j.gecco.2019.e00899

Korneeva E., Olinder N., Strielkowski W. (2021). Consumer attitudes to the smart home technologies and the internet of things (IoT). Energies 14(23). https://doi.org/10.3390/en14237913

Mathew P., Sreejesh S. (2017). Impact of responsible tourism on destination sustainability and quality of life of community in tourism destinations. Journal of Hospitality and Tourism Management 31: 83-89. https://doi.org/10.1016/j.jhtm.2016.10.001

Megahed N., Ghoneim E. (2020). Antivirus-built environment: Lessons learned from Covid-19 pandemic. Sustainable Cities and Society 61. https://doi.org/10.1016/j.scs.2020.102350

Mihalic T. (2020). Concpetualising overtourism: A sustainability approach. Annals of Tourism Research 84. https://doi.org/10.1016/j.annals.2020.103025

Mitsche N., Strielkowski W. (2016). Tourism e-services and Jewish heritage: A case study of Prague. European Journal of Tourism, Hospitality and Recreation 7(3): 203-211. https://doi.org/10.1515/ ejthr-2016-0022

Moravčíková E., Dvořák M. (2018). Changes in the structure and financial performance of firms of tourism in regions of the Slovak Republic, pp. 541-548. In: Klímová V., Žítek V. (eds.) $21^{\text {st }}$ International Colloquium on Regional Sciences. Conference Proceedings. Brno: Masarykova univerzita. https://doi.org/10.5817/CZ.MUNI.P210-8970-2018-71

Musavengane R., Kloppers R. (2020). Social capital: An investment towards community resilience in the collaborative natural resources management of community-based tourism schemes. Tourism Management Perspectives 34. https://doi.org/10.1016/j.tmp.2020.100654

Palazzo M., Vollero A., Vitale P., Siano A. (2021). Urban and rural destinations on Instagram: Exploring 
the influencers' role in sustainable tourism. Land Use Policy 100. https://doi.org/10.1016/j. landusepol.2020.104915

Qiu R., Park J., Li S., Song H. (2020). Social costs of tourism during the COVID-19 pandemic. Annals of Tourism Research 84. https://doi.org/10.1016/j.annals.2020.102994

Radovic D., Strielkowski W., Wang J., Cepel M., Rausser G. (2017). Economic analysis of sustainable tourism: a case study of Nottingham. Transformations in Business \& Economics 16(2B): 703-714.

Rasoolimanesh S., Ramakrishna S., Hall C., Esfandiar K., Seyfi S. (2020). A systematic scoping review of sustainable tourism indicators in relation to the sustainable development goals. Journal of Sustainable Tourism 1-21. https://doi.org/10.1080/09669582.2020.1775621

Rausser G., Strielkowski W., Štreimikienè D. (2018). Smart meters and household electricity consumption: A case study in Ireland. Energy \& Environment 29(1): 131-146. https://doi. org/10.1177/0958305X17741385

Romero I., Fernandez-Serrano J., Caceres-Carrasco F. (2020). Tour operators and performance of SME hotels: Differences between hotels in coastal and inland areas. International Journal of Hospitality Management 85. https://doi.org/10.1016/j.ijhm.2019.102348

Sahoo P., Ashwani. (2020). COVID-19 and Indian economy: Impact on growth, manufacturing, trade and MSME sector. Global Business Review 21(5): 1159-1183. https://doi. org/10.1177/0972150920945687

Severová L., Šrédl K., Prášilová M., Svoboda R., Soukup A., Dvořák M., Prachařová J. (2021). Change in the structure of the accommodation capacity of the Czech hotel industry under conditions of economic globalization. sustainability 13(16). https://doi.org/10.3390/su13169064

Simionescu M., Strielkowski W., Tvaronavičienè M. (2020). Renewable energy in final energy consumption and income in the EU-28 countries. Energies 13(9). https://doi.org/10.3390/en13092280

Streimikiene D., Korneeva E. (2020). Economic impacts of innovations in tourism marketing. Terra Economicus 18(3): 182-193. https://doi.org/10.18522/2073-6606-2020-18-3-182-193

Strielkowski W. (2017). Social and economic implications for the smart grids of the future. Economics \& Sociology 10(1): 310-318. https://doi.org/10.14254/2071-789X.2017/10-1/22

Strielkowski W. (2018). Lucrative circus in the desert: Economics of Burning Man. Preprints, 2018080399. https://doi.org/10.20944/preprints201808.0399.v1

Strielkowski W., Kasl Kollmannová D. (2014). Mystery and thriller tourism in European cultural destinations. Tourismos 9(1): 293-306.

Strielkowski W., Firsova I., Lukashenko I., Raudeliūnienè J., Tvaronavičienè M. (2021a). Effective management of energy consumption during the COVID-19 pandemic: The role of ICT solutions. Energies 14(4): 893. https://doi.org/10.3390/en14040893

Strielkowski W., Dvořák M., Rovný P., Tarkhanova E., Baburina N. (2021b). $5 \mathrm{G}$ wireless networks in the future renewable energy systems. Frontiers in Energy Research 9. https://doi.org/10.3389/ fenrg.2021.714803

Strielkowski W., Tumanyan Y., Kalyugina S. (2016). Labour market inclusion of international protection applicants and beneficiaries. Economics \& Sociology 9(2): 293-302. https://doi. org/10.14254/2071-789X.2016/9-2/20

Troshin A., Sokolova A., Ermolaeva E., Magomedov R., Fomicheva T. (2020). Information technology in tourism: Effective strategies for communication with consumers. Journal of Environmental Management \& Tourism 11(2(42)): 322-330. https://doi.org/10.14505//jemt.v11.2(42).10

Turner F. (2009). Burning Man at Google: a cultural infrastructure for new media production. New Media \& Society 11(1-2): 73-94. https://doi.org/10.1177/1461444808099575

Tussyadiah I. (2020). A review of research into automation in tourism: Launching the annals of tourism research curated collection on artificial intelligence and robotics in tourism. Annals of Tourism Research 81. https://doi.org/10.1016/j.annals.2020.102883 
Venugopalan T. (2019). Sustainability of tourism in India: Perception of tourists on Delhi tourism. Research Journal of Humanities and Social Sciences 10(2): 635-645. https://doi. org/10.5958/2321-5828.2019.00103.7

Wassie S. (2020). Natural resource degradation tendencies in Ethiopia: a review. Environmental Systems Research 9(1): 1-29. https://doi.org/10.1186/s40068-020-00194-1

Yfantidou G., Matarazzo M. (2017). The future of sustainable tourism in developing countries. Sustainable Development 25(6): 459-466. https://doi.org/10.1002/sd.1655

Yfantidou G., Spyridopoulou E., Kouthouris C., Balaska P., Matarazzo M., Costa G. (2017). The future of sustainable tourism development for the Greek enterprises that provide sport tourism. Tourism Economics, 23(5), 1155-1162. https://doi.org/10.1177/1354816616686415

Zheng D., Liang Z., Ritchie B. (2020). Residents' social dilemma in sustainable heritage tourism: The role of social emotion, efficacy beliefs and temporal concerns. Journal of Sustainable Tourism 28(11): 1782-1804. https://doi.org/10.1080/09669582.2020.1760288 